\title{
Short-run and long-run performance of IPOs: evidence from Taiwan stock market
}

\author{
Yue-Fang Wen*, Minh Huong Cao \\ Department of Applied Economics and Management, Ilan University, Ilan City, Taiwan
}

Email address:

yfwen@niu.edu.tw (Y. F. Wen)

\section{To cite the article:}

Yue-Fang Wen, Minh Huong Cao. Short-Run and Long-Run Performance of IPOs: Evidence from Taiwan Stock Market. Journal of Finance and Accounting. Vol. 1, No. 2, 2013, pp. 32-40. doi: 10.11648/j.jfa.20130102.12

\begin{abstract}
This paper studies the aftermarket stock performance of IPOs in short-run and long-run, and examines whether the long-run underperformance exists in Taiwan stock market. This paper applies the measure of expected skewness to verify that the highly expected skewed IPO firms are overpriced and experience the long-run underperformance. We find that IPO firms are underpriced $48.54 \%$ and severely underperform from three to five years in comparison to the reference portfolios. Skewness is reported to be positively related with the underpricing level of the first day. However, our findings suggest that this skewness measure can't explain for the long-run phenomenon of IPOs.
\end{abstract}

Keywords: IPO, Aftermarket Performance, Expected Skewness

\section{Introduction}

Examining the existence of IPOs' long-run underperformance has a significant implication. First, as Ritter [30] asserts, the long-run systematic price patterns challenge the efficient market hypothesis. Second, it encourages the active trading strategies of investors who are fortunate to receive IPO share allocation, and they will sell the shares immediately. Third, it implies that cost of external equity capital for an issuing firm will be lower. Additionally, there is considerable variation in the measures of abnormal returns and the statistical tests that empirical researchers are used to detecting long-run abnormal stock returns.

Numerous studies have examined the long-run performance of initial public offerings. Ritter [30] and Loughran and Ritter [26] whose studies on U.S. sample of IPOs report the severe underperformance of IPOs relative to a benchmark portfolio from three to five years after the IPO date. The poor long-run performance of IPOs has also been well documented in other markets. Levis [24], Keloharju [19] and Kooli and Suret [21] also find the underperformance in British, Finland, and Canadian. This phenomenon is not limited to developed countries but also extends to emerging markets. Aggarwal et al. [3] examine IPOs in Brazil, Chile, and Mexico that report short-term returns of $78.5 \%, 16.7 \%$, and $2.8 \%$, respectively.

While developed countries report a persistent result of long-run underperformance, emerging countries have mixed results. Dawson [15] examines the 1-year marketadjusted return for IPOs in HK, Singapore, and Malaysia during 1978-1984. While the underperformance in HK and Singapore is insignificant, Malaysia IPOs over-perform $18.2 \%$ significantly. The same result of Malaysian IPOs with high long-term return up to 3-year after listing is reported in Jelic et al. [18]. Kim et al. [20] study on 169 IPOs listed on KSE during 1985-1989, revealing that the Korean IPOs outperform seasoned firms with similar characteristics in the first month, quite not statistically different from seasoned firms in the long-run.

Not only examining the existence of long-run underperformance, many researchers suggest some hypotheses to explain the anomaly. Aggarwal and Rivoli [2] suggest that IPOs are subject to overvaluation or fads caused by over-optimism on the part of investors. Miller [29] argues that divergence of opinions among investors arises, and investors who hold the most optimistic expectation will lead the demand for a particular security. Over time, as the restriction weakens and more information is revealed, share price will be corrected. Teoh et al. [32] suggest the overstated earning management by accounting adjustment can fool rational investors, and that leads to the underperformance in the long-run when investors adjust the share prices. Barberis and Huang [7] study the pricing of financial securities in cumulative prospect theory framework, and suggest that some investors may choose to 
hold large undiversified position and are willing to pay a very high price for the skewed securities if new security is sufficiently skewed. Thus the skewed securities can become overpriced and earn a very low average return, which can explain for the low long-run average return on IPO stocks.

In Taiwan, the long-run performance has mixed results. Chen [12] employs multi-factor models and Jensen's alpha to measure the raw and market-adjusted return of long-run performance. He argues that the performance of IPOs in Taiwan is sensitive to the measurement models of expected returns. Under the market adjusted return, the IPOs perform better than the market while IPOs underperform in the long-run if size and book-to-market effects are taken into consideration. A later study conducted by Cheng and Shiu [13] employs monthly trimmed buy-and-hold excess return and cumulative abnormal return, and finds a negative threeyear abnormal return.

This paper aims to examine the aftermarket performance of Taiwanese IPO stocks extending to five years after the IPO date, and study whether they outperform or underperform comparing to the portfolio benchmark. Later, we try to verify if the ex-ante skewness has an explanatory power to predict the initial underpricing and long-run performance of IPO stocks, as the result suggested by Barberis and Huang [7].

The outline of this paper is as follows. In the second section, we review previous studies on the role of security's skewness. Next section discusses the research method including the sample and variables. In the fourth section we present the empirical results. The last section offers some concluding remarks.

\section{Previous Study on Security's Skewness}

Skewness is a measure of the asymmetry of frequency distribution (Aczel [1]). Distribution can be either skewed to the left or to the right. Positive skew (right-skewed) distribution will have a long tail extending to the right, which the mean and median are both greater than the mode.

Literature suggests that skewness plays an important role in the risky decision-making. Analysis of actual gambling behavior indicates that both gamblers on horse races and lottery have a preference for positive skewness and they will accept a lower expected payoff in return for greater skewness. Asterbro et al. [4] conduct a laboratory experiment to investigate how positive skew influences risky choices. They find that risk-averse choices decrease monotonically with an increase in skewness indicating skew-seeking choices. This means that with a preference for skewness, a risk-averse individual will accept a lowerexpected return (but not a negative one) or a higher level of overall risk if the distribution of payoffs is more skew to the right. Not only applicable for explaining the gamble behavior, skewness also plays a role in modern asset pricing model. While traditional theory on asset pricing only relies on the mean and variance features of the asset allocation, considerable evidences show that investor preferences go beyond mean and variance to higher moments: skewness and kurtosis (Xiong and Idzorek [33]). Rubinstein [31] and Kraus and Litzenberger [23] develop models of expected returns that incorporate skewness, and find that the co-movement with the aggregate market portfolio is a higher moment relevant for individual securities.

Other recent papers suggest that additional features of individual securities' payoff distribution may be relevant for understanding differences in assets' returns. Barberis and Huang [7] study the pricing of financial securities when investors make decisions according to cumulative prospect theory. Their results show that probability weighting can have unusual pricing effects in an economy with a positively skewed security. If a new security is sufficiently skewed, some investors may choose to hold large undiversified positions in it, thereby making the distribution of their overall wealth lottery-like. Since investors of cumulative prospect theory overweight the tails of a probability distribution, they love lottery-like distributions and therefore are willing to pay a very high price for the skewed securities. Thus the skewed securities can become overpriced, relative to the price that would be set by investors who do not weight probabilities, and thus earn a very low average return. Their results suggest the explanation for low long-run average return on IPO stocks under the cumulative prospect theory. Nonetheless, the security needs to be sufficiently positively skewed before investors are willing to take undiversified positions in it, and compensate for the lack of diversification in their portfolios.

However, the framework and assumption of Barberis and Huang [7] explaining the role of expected skewness with asset prices are similar to the optimal expectation theory of Brunnermeier and Parker [10] and Brunnermeier et al. [9]. In their studies, Barberis and Huang [7] suggest the distinct difference in cumulative prospect theory's prediction. They assert that negatively skewed asset will earn a high average return, while optimal expectation predicts the contradict result. Therefore, this is a premise for us to set up a hypothesis on relation between expected skewness and long-run performance based on cumulative prospect theory.

Conrad et al. [14] examine the relation of ex-ante skewness with expected stock returns in option price of individual stocks. The result is consistent with Barberis and Huang [7] and Brunnermeier et al. [9], which predicts that investors will trade off the benefits of diversification and skewness, and hold more concentrated positions in skewed securities, resulting negative relation between idiosyncratic skewness and expected returns.

Green and Hwang [17] use the approach of Zhang [34] to examine the effect of high expected skewness stocks with initial returns and long-run performance. They find that IPOs with high expected skewness experience significantly greater first-day return. The skewness effect is stronger 
during periods of high investor sentiment and is related to differences in skewness across industries as well as timeseries variation in the overall level of market skewness. IPOs with high expected skewness earn more negative abnormal returns in 1-5 years. In addition, their results show that the underperformance of IPOs pertains significant only with highly expected skewness, while the medium and low expected skewness are insignificant.

\section{Data and Methodology}

\subsection{Data}

To examine the aftermarket performance of IPO firms extending to five years after the initial trading, this paper tests the IPO sample with issue date ranging from March 2005 to 2007 . Therefore it will cover the stock return data from 2005 to 2012. The sample consists of 121 IPOs of common stocks listed on Taiwan Stock Exchange (TSE) and OTC market (GRETAI), and stocks transferring from OTC market to TSE market as well as the stocks of financial industry are already excluded. All the data are extracted from Taiwan Economic Journal (TEJ) database.

Table 1. Distributions of IPOs by year and industry

\begin{tabular}{ll}
\hline Panel A: Distribution of IPOs by issuing year \\
\hline Year & Number of IPOs \\
2005 & 37 \\
2006 & 34 \\
2007 & 50 \\
Total & 121 \\
Panel B: Distribution of IPOs by industry (*: Electronic related industries) \\
Industry & Number of IPOs \\
Biotech \& Medical & 5 \\
Building Material & 1 \\
Chemical & 2 \\
Communication \& Internet & 7 \\
Computer \& Peripheral & 13 \\
Elec. Parts \& Component & 25 \\
Elec. Products Distribution & 3 \\
Electric \& Machinery & 6 \\
Information Service & 2 \\
Iron \& Steel & 3 \\
Optoelectronic & 20 \\
Other Electronic & 11 \\
Others & 4 \\
Semiconductor & 121 \\
Trading & \\
Total & \\
\hline & \\
&
\end{tabular}

The reason why March 2005 is chosen to be the beginning for the study of IPOs aftermarket performance is that the price limit rule in Taiwan is loosened for IPOs since March 2005. Therefore, in the first five trading day, IPO stocks can be freely traded without $7 \%$ price limit on price fluctuation, which is more efficient to reflect the true investors' expectation with the new issues. Before this rule is enacted, insufficient supply in the aftermarket of IPOs might happen if the investors expected the intrinsic value higher than 7 percent of the offer price. Therefore, in this period the excess initial return in the honeymoon period is considered as the level of underpricing. By solely examining from March 2005, this paper considers the excess initial return on the first trading day will be used to measure the underpricing. The aftermarket period includes the 60 months following the issue, where months are defined as 21-trading-day interval, i.e. a 1-year window with 252 trading days, a 3-year window with 756 trading days, and 1,260 trading days for a 5-year period. The first trading month is started from the second day after the IPO date. Distributions of IPOs are displayed by year and industry as Table 1.

\subsection{Measurement Method}

\subsubsection{Underpricing Measurement}

From March 2005, IPO stocks are freely traded without $7 \%$ price fluctuation limit for the first five trading days. Therefore, it is expected that the excess initial return reflects all the demand and expectation of investors with the issuing of IPO stocks. Therefore, underpricing is defined as:

$$
U P_{i}=\frac{P_{1}}{P_{0}}-\frac{R_{m t_{1}}}{R_{m t_{0}}}
$$

Where $\mathrm{P}_{1}$ is the closing price on the first trading day of the IPO, and $\mathrm{P}_{0}$ is the offering price of IPO; $\mathrm{R}_{\mathrm{mt} 1}$ is the market index at the end of the first trading day, and $\mathrm{R}_{\mathrm{mt} 0}$ is the market index at the end of a trading day before the IPO issue date.

\subsubsection{Long-Run Return Measurement}

The proper method to measure long-run returns is widely debated. A growing amount of literature questions the methodology used in many empirical long-horizon studies. Barber and Lyon [5], Kothari and Warner [22], Barber et al. [6], and Fama [16] all argue that the method of performance measurement influences both the magnitude of the abnormal returns as well as the size and the power of the statistical test.

There are two choices of long-run return measurement: cumulative abnormal return (CAR) and buy and hold return (BHR). In the study of Barber and Lyon [5], they assert that CAR is a biased predictor of long-run buy and hold abnormal returns. Cumulative abnormal returns are subject to a measurement bias, a new listing bias, and a skewness bias. Consequently, they favor the use of the BHR method 
in test design to detect the long-run abnormal stock returns. This paper applies the buy-and-hold abnormal returns (BHARs) over three- and five-year periods following the offering to measure the long-run stock performance. Abnormal returns are estimated via the size and the bookto-market reference portfolio approaches.

At the end of year before the IPO, all the stocks on market are first ranked by size and created 10 deciles based on the market value, then they are sorted each of 10 size deciles into five additional portfolios on the base of bookto-market $(\mathrm{B} / \mathrm{M})$ ratio. After the sorting, we create 50 portfolios based on size and book-to-market ratio. Then each IPO firms will match with one reference portfolio that has the same size and close $\mathrm{B} / \mathrm{M}$ ratio. The size of IPO firms is measured as the market value of common equity (share outstanding multiplied with closing price on the first day), while the $\mathrm{B} / \mathrm{M}$ ratio for IPO firms using the first recorded post-issue book value, and the market capitalization using the closing market price on the first trading day.

Matching portfolios are not re-ranked again to avoid the new listing bias and rebalancing bias. The reference portfolios returns are calculated by equally weighting the returns of firms in portfolios. Buy-and-hold return for horizon $t$ is defined as:

$$
B H A R_{k \tau}=\prod_{t=2}^{\tau}\left(1+R_{i t}\right)-\prod_{t=2}^{\tau}\left(1+C R_{i t}\right)
$$

BHAR: the buy-and-hold abnormal return.

$R_{i t}$ : the buy-and-hold return of IPO firm at month $\mathrm{t}$.

$C R_{j t}$ : the buy-and-hold return for the reference portfolio.

All the investment returns are adjusted returns which are already adjusted for stock dividends and stock split events, and they are calculated as below:

$$
R_{i t}=\frac{\left(P_{t} *(1+\alpha+\beta)+D\right)}{\left(P_{t-1}+\alpha * C\right)}-1
$$

$P_{t}:$ closed price in $\mathrm{t}$.

$\alpha$ : purchase rate in current ex-right.

$\beta$ : stock dividend in current ex-right.

$C$ : buy price in current ex-right.

$D$ : dividend amount.

To test the robustness of long-run abnormal returns, this paper applies the conventional t-statistic mentioned in Barber and Lyon [6] to test the null hypothesis that the mean of buy-and-hold abnormal return is equal to zero for a sample of $\mathrm{n}$ firms. The conventional t-statistic is defined as:

$$
t=\frac{\overline{\text { BHAR }_{T}}}{S\left(\text { BHAR }_{T}\right) / \sqrt{n}}
$$

$\overline{\text { BHAR }_{T}}: \frac{1}{n} * \sum_{i=1}^{n} B H A R_{i T}$

$S\left(B H A R_{T}\right)$ : the standard deviation of abnormal returns.

\subsubsection{Expected Skewness Measurement}

In order to capture the events of small probabilities, ex- ante skewness is needed to use a long history of returns which raises the concern of survivorship bias. In addition, it can overlook the possibility that the stock's skewness can dramatically change over its life cycle. Zhang [34] finds an alternative method to measure expected skewness by using group approach. He groups similar stocks with similar characteristics such as industry, size or B/M ratio and calculate cross-sectional skewness with recent returns. By using only recent returns, this method avoids long history dependence. Moreover, it is more likely to capture events of small probabilities with group of stocks than time periods.

Following Zhang [34] and Green and Hwang [17], the expected skewness is measured as:

$$
\text { Skew }_{i, t}=\frac{\left(P_{99}-P_{50}\right)-\left(P_{50}-P_{1}\right)}{P_{99}-P_{1}}
$$

$\mathrm{P}_{j}$ is the $j$ th percentile of the $\log$ monthly return distribution pooled across all stocks of $\mathrm{IPO}_{i}$ over three months preceding the offering within the industry assigned by TSE. The distribution is right skewed, if the right tail is further away from the median than the left tail, or Skew receives a positive value. The denominator controls for the dispersion of the distribution.

Since companies within an industry share similar characteristics and technologies and react to the same macroeconomics factors, assigning an industry-level to calculate expected skewness likely produce a good estimator. Newly listing firms likely have high expected skewness if their industries recently have high returns. The classification of industries follows the industry classification assigned by TSE.

\subsection{Regression Model and Definition of Variables}

Multiple regression models are used to test the post-IPO stock performance and the association between the expected skewness and level of underpricing. Dependent variables are underpricing level and BHAR five-year stock performance, while the expected skewness is the independent variable. We include along a variety of control variables based on firm's characteristics, deal characteristics, industry conditions, and market conditions. The description and justification of control variables are presented below:

\subsubsection{Firm's Characteristics}

\section{(1) Age (Age)}

The age variable is defined as the year from the firm's establishment to the IPO date. Beatty and Ritter [8] suggest that young firms' returns tend to be more positively skewed than older firms' returns, therefore more underpriced in the first day trading. Ritter [30] asserts that younger IPO firms underperform more than the established firms in the longrun. Hence, Age is expected to have negative relation with underpricing, while it is positively related with long-run performance. 
(2) Industry Dummy (Electronic)

The industry variable will receive a value of 1 for electronic firms, otherwise the value is 0 . Lowry and Shu [27] suggest the severe underpricing of high-tech IPOs due to the uncertainty with their future growth opportunities. Hence, Electronic is expected to be positively related with severe underpricing.

(3) Market $(M K)$ :

A dummy variable is determined whether the IPO is listed on TSE (value of 1) or OTC (value of 0 ). Since the listing criteria of OTC exchange are lower than TSE, IPO stocks listed on TSE tend to have stronger financial background and information exposed.

\subsubsection{Deal Characteristics}

(1) Offering Size (OS)

The offering size is defined as the natural logarithm of total proceeds as follows.

$$
\text { OS }=\ln \left(\text { Offer price } * \text { IPO outstanding stock on } 1^{\text {st }}\right. \text { day) }
$$

Ritter [30] finds that small offerings tend to have worse long-run aftermarket performance compared to large offerings, and the sign of variable coefficient is predicted to be positive.

(2) Underwriter Prestige (Pres)

Logue [25] finds a negative relation between underwriter prestige and the degree of underpricing. Carter et al. [11] show that IPOs with prestigious underwriters experience better long-term performance. Following Megginson and Weiss [28], the underwriter prestige is measured as:

Pres $_{i}=$ Market share of the lead underwriter/Total IPO proceeds in 2005-2007 (7)

\subsubsection{Market and Industry Condition}

To control for whether the volatility of recent IPO issue, the return, momentum, and turnover of industry may affect the expectation of investors toward the questioned IPOs, therefore associate with the expected skewness and level of underpricing, we also include them in the regression.

(1) IPO Volatility (IPOV)

The IPO volatility measures the volatility of initial return of IPOs over three months prior to the IPO issue.

(2) Industry Return (INDR)

The industry return is defined as the IPO's industry return over month $\mathrm{t}-1$.

(3) Industry Momentum (INDM)

The industry momentum is the cumulative industry return over month $\mathrm{t}-13$ to $\mathrm{t}-2$.

(4) Industry Turnover (INDT)

The industry turnover is defined as the average industry turnover over month $\mathrm{t}-1$.

\section{Results and Discussion}

\subsection{Descriptive Statistics}

Table 2 lists the descriptive statistics for all variables of IPOs sample. The underpricing (UP) is noticeably high in this period $(48.54 \%)$, as the result of removing limit on price fluctuation on first-five trading day. The mean of Skew variable is positive, suggesting that recent industry stock return is favorable prior to the IPO issues. Therefore, investors may place high expectation on good future return of IPO in the same industry. The sample is dominant by number of electronic IPO stocks (79\%), and it may raise the concern that the result in this study only applicable for Taiwanese electronic sector. In addition, the number of IPO listed on TSE is $23 \%$ (27 firms) compared with $77 \%$ listed on OTC (94 firms). Table 3 describes the correlation matrix between these variables.

Table 2. Variables'descriptive statistics

\begin{tabular}{lccccc}
\hline Variables & Obs & Mean & St. Dev & Min & Max \\
\hline Underpricing (UP) & 121 & 0.4854 & 0.8616 & -0.121 & 7.2755 \\
Skewness (Skew) & 121 & 0.1146 & 0.1708 & -0.426 & 0.5418 \\
Age (Age) & 121 & 14.3231 & 8.6889 & 1.5 & 51.2 \\
Industry dummy (Electronic) & 121 & 0.7933 & 0.4065 & 0 & 1 \\
Market (MK) & 121 & 0.2314 & 0.4234 & 0 & 1 \\
Offering size (OS) & 121 & 14.7047 & 1.1854 & 12.68 & 18.8266 \\
Underwriter prestige (Pres) & 121 & 0.0591 & 0.0393 & 0.0014 & 0.1693 \\
IPO volatility (IPOV) & 121 & 19.4818 & 24.1344 & 0.5483 & 89.4619 \\
Industry return (INDR) & 121 & 1.0919 & 8.9897 & -15.52 & 34.78701 \\
Industry turnover (INDT) & 121 & 23.8144 & 12.7768 & 4.5867 & 68.7445 \\
Industry momentum (INDM) & 121 & 36.3391 & 42.0908 & -33.69 & 129.635 \\
\hline
\end{tabular}




\subsection{IPO Aftermarket Performance}

Table 4 reports the aftermarket performance of Taiwanese IPO firms from 1-year to 5- year event windows, and both the conventional t-test and skewness-adjusted ttest are used to examine the possibility of zero mean. On average, the post-IPO BHARs over the 1-year, 3-year, and 5 -year are $-6.2 \%,-34 \%$ and severe $-55 \%$ respectively. In the first year, the underperformance of IPOs firm is slightly small and insignificant, while the level of abnormal return and significance are high for 3-year and 5-year windows.
Hence, we conclude that Taiwan IPOs perform comparably toward the matching size and $\mathrm{B} / \mathrm{M}$ reference portfolios after 1-year period.

Given the fact that the level of underpricing is really high $(48.54 \%)$ on the first trading day, this result suggests that market gradually adjust the stock performance of IPO firms after first year of trading. However, the longer-event window results prove that this trend continue to enlarge in the long-run, and IPOs firm underperform compared with those firms have similar size and $\mathrm{B} / \mathrm{M}$ ratio.

Table 3. Correlation matrix between regression variables

\begin{tabular}{|c|c|c|c|c|c|c|c|c|c|c|c|c|}
\hline Variables & $U P$ & BHAR36m & Skew & Age & Electronic & MK & OS & Pres & IPOV & INDR & INDT & INDM \\
\hline $\boldsymbol{U P}$ & 1.000 & & & & & & & & & & & \\
\hline Skew & $\begin{array}{l}0.157 * \\
(0.084)\end{array}$ & $\begin{array}{l}0.048 \\
(0.598)\end{array}$ & 1.000 & & & & & & & & & \\
\hline Age & $\begin{array}{l}-0.189 * * \\
(0.037)\end{array}$ & $\begin{array}{l}0.137 \\
(0.133)\end{array}$ & $\begin{array}{l}0.070 \\
(0.446)\end{array}$ & 1.000 & & & & & & & & \\
\hline Electronic & $\begin{array}{l}-0.078 \\
(0.392)\end{array}$ & $\begin{array}{l}0.075 \\
(0.409)\end{array}$ & $\begin{array}{l}0.065 \\
(0.477)\end{array}$ & $\begin{array}{l}-0.170 * \\
(0.061)\end{array}$ & 1.000 & & & & & & & \\
\hline MK & $\begin{array}{l}-0.005 \\
(0.959)\end{array}$ & $\begin{array}{l}0.179 * * \\
(0.048)\end{array}$ & $\begin{array}{l}-0.110 \\
(0.225)\end{array}$ & $\begin{array}{l}-0.196 * * \\
(0.030)\end{array}$ & $\begin{array}{l}0.135 \\
(0.14)\end{array}$ & 1.000 & & & & & & \\
\hline Pres & $\begin{array}{l}-0.060 \\
(0.517)\end{array}$ & $\begin{array}{l}-0.060 \\
(0.511)\end{array}$ & $\begin{array}{l}-0.093 \\
(0.308)\end{array}$ & $\begin{array}{l}0.070 \\
(0.442)\end{array}$ & $\begin{array}{l}0.084 \\
(0.357)\end{array}$ & $\begin{array}{l}0.144 \\
(0.116)\end{array}$ & $\begin{array}{l}0.218 * * \\
(0.017)\end{array}$ & 1.000 & & & & \\
\hline IPOV & $\begin{array}{l}0.258 * * * \\
0.0042\end{array}$ & $\begin{array}{l}-0.023 \\
(0.800)\end{array}$ & $\begin{array}{l}0.285 * * \\
(0.0015)\end{array}$ & $\begin{array}{l}-0.002 \\
(0.98)\end{array}$ & $\begin{array}{l}0.098 \\
(0.283)\end{array}$ & $\begin{array}{l}0.042 \\
(0.647)\end{array}$ & $\begin{array}{l}0.109 \\
(0.232)\end{array}$ & $\begin{array}{l}-0.026 \\
(0.773)\end{array}$ & 1.000 & & & \\
\hline$I N D R$ & $\begin{array}{l}0.465 * * * \\
(0.001)\end{array}$ & $\begin{array}{l}-0.052 \\
(0.571)\end{array}$ & $\begin{array}{l}0.25 * * * \\
(0.005)\end{array}$ & $\begin{array}{l}-0.053 \\
(0.562)\end{array}$ & $\begin{array}{l}0.006 \\
(0.944)\end{array}$ & $\begin{array}{l}-0.099 \\
(0.278)\end{array}$ & $\begin{array}{l}-0.103 \\
(0.263)\end{array}$ & $\begin{array}{l}-0.034 \\
(0.713)\end{array}$ & $\begin{array}{l}0.226 * * \\
(0.012)\end{array}$ & 1.000 & & \\
\hline$I N D T$ & $\begin{array}{l}0.392 * * \\
(0.004)\end{array}$ & $\begin{array}{l}-0.120 \\
(0.19)\end{array}$ & $\begin{array}{l}0.233 * * * \\
(0.01)\end{array}$ & $\begin{array}{l}-0.181 * * * \\
(0.047)\end{array}$ & $\begin{array}{l}0.316 * * * \\
(0.000)\end{array}$ & $\begin{array}{l}0.003 \\
(0.971)\end{array}$ & $\begin{array}{l}0.153 * \\
(0.094)\end{array}$ & $\begin{array}{l}-0.093 \\
(0.308)\end{array}$ & $\begin{array}{l}0.410 * * * \\
(0.001)\end{array}$ & $\begin{array}{l}0.518 * * * \\
(0.001)\end{array}$ & 1.000 & \\
\hline INDM & $\begin{array}{l}0.256 * * * \\
(0.001)\end{array}$ & $\begin{array}{l}0.039 \\
(0.667)\end{array}$ & $\begin{array}{l}0.117 \\
(0.201)\end{array}$ & $\begin{array}{l}-0.150 \\
(0.108)\end{array}$ & $\begin{array}{l}0.203 * * \\
(0.025)\end{array}$ & $\begin{array}{l}0.236 * * * \\
(0.009)\end{array}$ & $\begin{array}{l}0.364 * * * \\
(0.001)\end{array}$ & $\begin{array}{l}-0.096 \\
(0.296)\end{array}$ & $\begin{array}{l}0.646 * * * \\
(0.001)\end{array}$ & $\begin{array}{l}-0.150 \\
(0.101)\end{array}$ & $\begin{array}{l}0.396 * * * \\
(0.001)\end{array}$ & 1.000 \\
\hline
\end{tabular}

This table provides coefficients of correlation ( $\mathrm{p}$-value in parentheses) of various variables.

$* \mathrm{p}<0.1 ; * \mathrm{p}<0.05 ; * * \mathrm{p}<0.01$.

Table 4. Aftermarket performance measured by buy-and-hold abnormal return

\begin{tabular}{lllll}
\hline $\begin{array}{l}\text { Event } \\
\text { period }\end{array}$ & Mean & Median & t-test & $\begin{array}{l}\text { Adjusted Skew } \\
\text { t-test }\end{array}$ \\
\hline 1 - year & -0.0630 & -0.1330 & -1.05 & -0.92 \\
3 - year & $\mathbf{- 0 . 3 4 0 4 * * *}$ & -0.6473 & -3.29 & -2.60 \\
\hline 5 - year & $\mathbf{- 0 . 5 5 1 2 * * *}$ & -0.6838 & -5.11 & -2.52 \\
\hline
\end{tabular}

$* \mathrm{p}<0.1 ; * * \mathrm{p}<0.05 ; * * * \mathrm{p}<0.01$

\subsection{Regression Results}

As stated in section 1, the recent finance literature suggests the role of skewness in explaining the difference in asset pricing and return. Barberis and Huang [7] assert that investors with preference for skewness are willing to pay a very high price for skewed securities, which makes the securities overprice the prices more than the normal investors are willing to pay, thus earn a very low average return. Hence, ex-skewness of IPOs is predicted to be positively related with the degree of underpricing, while negatively related to the long-run performance of IPO stocks. 
First, IPO stocks are sorted on the base of Skew then formed into three skew sub-groups including: low skewed (25\%), medium (50\%) and high-skewed (25\%). Then, we examine the level of underpricing and 3-year BHARs for each sub-skew group in Table 5, and find that underpricing for the high group is significantly higher in magnitude compared to the low-skewed group. However, 3-year BHARs for the high-skewed group is more positive and indifferent compared with the low and medium skewed groups. This result is contradicted with our prediction about the negative relation between highly-skewed and long-run average return.

We next adopt multiple regression models to examine the
post-IPO stock performance and the association of expected skewness and the underpricing level. Table 6 reports the regression results for the relation between the expected skewness and the underpricing level. Aside from the testable relationship in column $\# 1$, we expand the model to count for the effect of control variables (firms and deal characteristics, market and industry conditions). In model \#2 and model \#3, the effects of skewness are still significantly positive when firm's characteristics (variables of Age, electronic, and $M K$ ) and deal characteristics (variables of $O S$ and Pres) are controlled in the regression.

Table 5. Comparison of underpricing and three-year BHARs between skew sub-groups

\begin{tabular}{llllll}
\hline Skew group & Observation & $\begin{array}{l}\text { Underpricing } \\
\text { Mean }\end{array}$ & Median & BHAR36m & Mean \\
\hline Low & 31 & 0.2308 & 0.0848 & -0.3133 & -.6395 \\
Medium & 61 & 0.5198 & 0.1487 & -0.4239 & -.6704 \\
High & 29 & 0.6855 & 0.4552 & -0.2045 & -.5302 \\
$\begin{array}{l}\Delta \text { (High-Low) } \\
\text { t-value for mean difference }\end{array}$ & & $\mathbf{0 . 4 5 4 7 * * *}$ & $\mathbf{0 . 3 7 0 4 * * *}$ & -0.1087 & -0.3337 \\
$\begin{array}{l}\text { Wilcoxon z-value for } \\
\text { median difference }\end{array}$ & 3.2893 & & & 0.096 \\
\hline
\end{tabular}

${ }^{*} \mathrm{p}<0.1 ; * * \mathrm{p}<0.05 ; * * * \mathrm{p}<0.01$

Table 6. The relation between expected skewness and IPO underpricing

\begin{tabular}{|c|c|c|c|c|c|c|c|c|}
\hline Variables & Model \# 1 & & Model \# 2 & & Model \# 3 & & Model \# 4 & \\
\hline & Coef. & t-stat & Coef. & t-stat & Coef. & t-stat & Coef & t-stat \\
\hline Intercept & $0.0936 * * *$ & 4.21 & $0.9219 * * *$ & 3.91 & 1.3022 & 1.04 & $2.0647^{*}$ & 1.92 \\
\hline Skew & $0.7935^{*}$ & 1.74 & $0.9086 * *$ & 2.00 & $0.9088 * *$ & 1.97 & 0.1558 & 0.38 \\
\hline Age & & & $-0.0224 * *$ & -2.46 & $-0.0225^{* *}$ & -2.42 & $-0.0142 *$ & -1.81 \\
\hline Electronic & & & -0.2694 & -1.39 & -0.2571 & -1.3 & $-0.3829 * *$ & -2.21 \\
\hline MK & & & -0.0244 & -0.13 & 0.0229 & 0.10 & 0.0411 & 0.21 \\
\hline$O S$ & & & & & -0.0261 & -0.3 & -0.1055 & -1.38 \\
\hline Pres & & & & & -0.2382 & -0.12 & 1.3555 & 0.78 \\
\hline IPOV & & & & & & & -0.0063 & -1.57 \\
\hline$I N D R$ & & & & & & & $0.051 * * *$ & 4.93 \\
\hline$I N D T$ & & & & & & & 0.0029 & 0.38 \\
\hline INDM & & & & & & & $0.0102 * * *$ & 3.84 \\
\hline $\mathrm{R}^{2}$ & 0.0248 & & 0.0812 & & 0.0822 & & 0.3915 & \\
\hline Adj. $\mathrm{R}^{2}$ & 0.0166 & & 0.0495 & & 0.0339 & & 0.3362 & \\
\hline F value & $3.02 * * *$ & & $2.56^{* * *}$ & & $1.7^{*}$ & & $7.08 * * *$ & \\
\hline $\mathrm{N}$ & 121 & & 121 & & 121 & & 121 & \\
\hline
\end{tabular}

$* \mathrm{p}<0.1 ; * * \mathrm{p}<0.05 ; * * * \mathrm{p}<0.01$

However, in model \#4, when we control for the fixed effect of market and industry conditions (variables of IPOV, $I N D R, I N D T$, and INDM), the explanatory power of skewness with underpricing becomes insignificant. Besides the consistent negative relation between Age and UP (underpricing), we find that industry return (INDR) over month $\mathrm{t}-1$ and industry momentum (INDM) over month t13 to $\mathrm{t}-2$ both have a positive relation with underpricing level. From this result, it is estimated that investors not only evaluate IPO stock by firm performance, but also consider 
about the trend and future prospect of industry. By using the previous three-month industry return to measure the IPO skewness as suggested by Zhang [34], our Skew measure is expected to has correlation with industry control variables and then the reduction in meaning power is not so confusing.

Table 7 reports the relation between expected skewness and IPO three-year BHAR. Regression result suggests that the expected skewness can't explain for the aftermarket underperformance of Taiwanese IPO firms. However, we find that underperformance in Taiwan is worsen for IPOs with bigger firms. This is consistent with the findings of Cheng and Shiu [13] who report that the mean of weighted buy-and-hold excess return is more negative $(-10.03 \%)$ than the equally weighted mean $(-3.411 \%)$.

In addition, Ritter [30] and Beatty and Ritter [8] find that young IPO firms underperform than the established firms in the long-run. Our findings support this explanation since younger firms have high growth opportunity and short operational history, so that greater uncertainty for investors to evaluate their true potential.

Finally, our findings suggest that the underperformance is lesser for IPOs firms listed on Taiwan Stock Exchange (TSE), rather than OTC Exchange (GRETAI). Strict listing requirements on previous performance before firms are accepted to list on TSE, and information disclosure rules provide investors more information to evaluate the true value of stock prices.

Table 7. The relation between expected skewness and three-year BHAR of IPO firms

\begin{tabular}{|c|c|c|}
\hline Variables & Coef. & t-value \\
\hline Intercept & $2.966^{*}$ & 1.76 \\
\hline Skewness (Skew) & 0.546 & 0.86 \\
\hline Age (Age) & $0.022 *$ & 1.84 \\
\hline Industry dummy (Electronic) & 0.44 & 1.62 \\
\hline Market $(M K)$ & $0.937 * * *$ & 2.99 \\
\hline Offering size $(O S)$ & $-0.258^{* *}$ & -2.14 \\
\hline IPO volatility $(I P O V)$ & -0.006 & -0.94 \\
\hline Industry return (INDR) & 0.014 & 0.89 \\
\hline Industry turnover (INDT) & -0.019 & -1.64 \\
\hline Industry momentum (INDM) & 0.005 & 1.41 \\
\hline $\mathbf{R}^{2}$ & 0.1498 & \\
\hline Adj. $R^{2}$ & 0.0725 & \\
\hline F value & $1.94 * *$ & \\
\hline Observation & 121 & \\
\hline
\end{tabular}

${ }^{*} \mathrm{p}<0.1 ; * * \mathrm{p}<0.05 ; * * * \mathrm{p}<0.01$

\section{Conclusion}

Given the mixed results about aftermarket performance of IPO firms listed on Taiwan stock markets, this paper aims to examine whether IPOs suffer from systemic underperformance in the long run. Using the buy-and-hold return measurement via the size and $\mathrm{B} / \mathrm{M}$ matching reference portfolios, conducted on 121 IPOs issued from March 2005 to 2007, we find that IPO firms are indifferent from reference portfolios in the first trading year, while suffer severe underperformance in three-year to five-year after the issue date. Given the high level of underpricing on the first day, individual investors start to suffer from stock price adjustment from the second trading day.

Second, this paper employs the skewness measurement suggested by Zhang [34], by using the previous industry return to examine if skewness plays a role in pricing the IPO stocks and enables to explain the long-run underperformance of IPO firms. Although it is reported to be positively related with the underpricing level of the first day, our findings suggest that this skewness measure can't explain for the long-run phenomenon of IPOs. However, due to limitation in sample size and hand-crossing process, this paper suggests that further researches could examine the implication of cumulative prospect theory in explaining the long-run underperformance of Taiwan IPOs.

\section{References}

[1] Aczel, A.D. (1989). Complete Business Statistics. Homewood IL: Irwin.

[2] Aggarwal, R. and Rivoli, P.(1990), "Fads in the Initial Public Offerings market?" Financial Management, 19, 4557.

[3] Aggarwal, R., Leal, R., and Hernandez, L.(1993), "The Aftermarket Performance of Initial Public Offerings in Latin America," Financial Management, spring, 42-53.

[4] Asterbro, T., Mata, J., and Pinto, S. L. (2011), "Preference for Skew in Lotteries: Evidence from the Laboratory," Working paper. HEC Paris.

[5] Barber, M. B. and Lyon, D. J. (1997), "Detecting Long-Run Abnormal Stock Returns: The Empirical Power and Specification of Test Statistics," Journal of Financial Economics, 43, 341-372.

[6] Barber, M. B., Lyon, D. J., and Tsai, C. L.(1999), "Improved Methods for Tests of Long-run Abnormal Stock Returns," Journal of Finance, 54(1), 165-201.

[7] Barberis, N. and Huang, M. (2008), "Stock as Lotteries: The Implications of Probability Weighting for Security Prices," American Economic Review, 98(5), 2066-2100.

[8] Beatty, P. R. and Ritter, J.R.(1986), "Investment Banking, Reputation and the Underpricing of Initial Public Offerings," Journal of Financial Economics, 15(1-2), 213232.

[9] Brunnermeier, K. M., Gollier, C., and Parker, A. J. (2007), "Optimal Beliefs, Assets Prices, and the Preference for 
Skewed Returns," American Economic Review, 97(2), 159165.

[10] Brunnermeier, K. M. and Parker, A. J. (2005), "Optimal Expectations," American Economic Review, 95(4), 10921118.

[11] Carter, R., Dark, F. H., and Singh, A.K.(1998), "Underwriter Reputation, Initial Returns, and the Long-Run Performance of IPO Stocks," Journal of Finance, 53, 285- 311.

[12] Chen, A. (2001), "The Long-Run Performance Puzzle of Initial Public Offerings in Taiwan: Empirical Findings from Various Models," Journal of Financial Studies, 9, 1-20.

[13] Cheng, S.R. and Shiu, C.Y. (2005), "Examination the LongRun Performance of Taiwanese Initial Public Offerings," Information and Management Sciences, 16(2), 17-34.

[14] Conrad, J., Dittmar, R., and Ghysels, E.(2013), "Ex-ante Skewness and Expected Stock Returns," Journal of Finance, 68(1), 85-124.

[15] Dawson, M.S. (1987), "Secondary Stock Market Performance of Initial Public Offers, Hong Kong, Singapore and Malaysia: 1978-1984," Journal of Business Finance and Accounting, spring, 65-76.

[16] Fama, F. E. (1998), "Market Efficiency, Long-Term Returns, and Behavioral Finance," Journal of Financial Economics, 49, 283-306.

[17] Green, T. C., and Hwang B. H. (2011), "Initial Public Offerings as Lotteries: Skewness Preference and First-Day Returns," Management Science, Articles in Advance, 1-13.

[18] Jelic, R., Saadouni, B., and Briston, R.J. (2001), "Performance of Malaysian IPOs: Underwriters' Reputation and Management Earnings Forecasts," Pacific-Basin Finance Journal, 9, 457-486.

[19] Keloharju, M. (1993), "The Winner's Curse, Legal Liability, and the Long-Run Price Performance of Initial Public Offerings in Finland," Journal of Financial Economics, 34(2), 251-277.

[20] Kim, J. B., Krinsky, I., and Lee, J. (1995), "The Aftermarket Performance of Initial Public Offerings in Korea," PacificBasin Financial Journal, 3, 429-448.

[21] Kooli, M. and Suret, J.M. (2004), "The Aftermarket
Performance of Canadian Initial Public Offerings," Journal of Multinational Financial Management, 14(1), 47-66.

[22] Kothari, S. P., and Warner, B. J. (1997), "Measuring LongHorizon Security Price Performance," Journal of Financial Economics, 43, 301-339.

[23] Kraus, A. and Litzenberger, H.R. (1976), "Skewness Preference and the Valuation of Risk Assets," Journal of Finance, 31(4), 1085-1100.

[24] Levis, M. (1993), "The Long-Run Performance of Initial Public Offerings: The UK Experience 1980 - 1988," Financial Management, 22(1), 28-41.

[25] Logue, D. (1973), "Premia on Unseasoned Equity Issues, 1965 - 1969," Journal of Economics and Business, 25, 133141

[26] Loughran, T. and Ritter, J.R. (1995), "The New Issues Puzzle," The Journal of Finance, 50(1), 23-51.

[27] Lowry, M. and Shu, S.(2002), "Litigation Risk and IPO Underpricing," Journal of Financial Economics, 65, 309335 .

[28] Megginson, W. and Weiss, K. (1991), "Venture Capitalist Certification in Initial Public Offerings," Journal of Finance, $39,1231-1237$.

[29] Miller, E. M.(1977), "Risk, Uncertainty, and Divergence of Opinion," Journal of Finance, 32(4), 1151-1168.

[30] Ritter, J. R. (1991), "The Long-Run Performance of Initial Public Offerings," The Journal of Finance, 46(1), 3-27.

[31] Rubinstein, M. E. (1973), "The Fundamental Theorem of Parameter-Preference Security Valuation," Journal of Financial and Quantitative Analysis, 8(1), 61-69.

[32] Teoh, S. H., Welch, I., and Wong, T. J. (1998), "Earnings Management and the Long-Run Market Performance of Initial Public Offerings," Journal of Finance, 53, 1935-1974.

[33] Xiong, X.J. and Idrorek, T. (2011), "The Impact of Skewness and Fat Tails on the Asset Allocation Decision," Financial Analysts Journal, 67(2), 23-35.

[34] Zhang, Y. (2006), "Individual Skewness and the CrossSection of Average Stock Returns," Working Paper, Yale University. 